\title{
Ethnic differences in use values and use patterns of Parkia biglobosa in Northern Benin
}

Kourouma Koura ${ }^{1 *}$, Jean C Ganglo ${ }^{1}$, Achille E Assogbadjo ${ }^{1}$ and Clément Agbangla ${ }^{2}$

\begin{abstract}
Background: African locust bean tree (Parkia biglobosa) is a multipurpose species used widely in arid Africa by local communities. The present study focused on ethnic differences in use values and use patterns of $P$. biglobosa in Northern Benin, where the species widely grows. The use values according to the various ethnic groups in the study area have been evaluated in detail for P. biglobosa.

Methods: From 13 ethnic groups, 1587 people were interviewed in the study area using semi-structured questionnaires. Principal Component Analysis was applied to analyze the use value and the use patterns of $P$. biglobosa for the different ethnic groups.
\end{abstract}

Results: All interviewees in the study area knew at least one use of P. biglobosa. The various uses identified were medicinal (47\%), handicraft and domestic (3\%), medico-magic (1\%), veterinary (1\%), cultural (1\%), food (25\%) and commercial (22\%). The various parts involved in these types of uses were: fruits [shell (2\%), pulp (22\%) and seeds $(36 \%)]$, bark (17\%), leaves (9\%), roots (3\%), flowers (1\%) and branches (10\%). The ethnic group consensus values for P. biglobosa parts showed that the seeds are used the most. The interviewees diversity value (ID) and equitability value (IE) indicated that knowledge concerning P. biglobosa use was distributed homogeneously among the ethnic groups.

Conclusions: $P$. biglobosa is well-known and used in different ways by the local populations in the study area. Local knowledge on the species is diversified and influenced by ethnic group. Ethnic differences in use values and use patterns of the species were evident in this study.

Keywords: Parkia biglobosa, quantitative ethnobotany, use value, use pattern, Benin

\section{Background}

In the Sahelian and Sudanian zones of West Africa, woody perennial parklands are very important for food security, especially during food shortage and drought periods [1]. Within these parkland systems, Parkia biglobosa species has important socio-economic and cultural values for local people. Moreover, it is a food species whose importance is well recognized both regionally and internationally [2]. In Benin, P. biglobosa is an important tree species which generates non-timber forest products $[3,4]$. It is a basic and therapeutic food and is a source of wealth [5]. The pulp of the fruit pods is rich in sucrose and the seeds are rich in carbohydrates,

\footnotetext{
* Correspondence: kourakourouma@yahoo.fr

${ }^{1}$ Faculty of Agronomic Sciences, University of Abomey-Calavi, Cotonou (01 PO Box 526), Benin

Full list of author information is available at the end of the article
}

proteins and lipids, thus constituting an important source of energy [6]. P. biglobosa is rated fifth important among thirty-one woody medicinal plants used in traditional medicine in Benin [4]. It is rated fourth from a list of eighteen priority food woody plants to preserve [7]. In association with crops, the species help to enrich physico-chemical soil characteristics which in turn help to increase crop yields.

It has been noted in Benin, that this species population is ageing. In addition, the natural regeneration of the species is very low $[8,9]$. Studies have indeed shown a decrease in the distribution of the species in Benin [10]. Due to the socio-economic and cultural importance of this species, communities tend to over utilize the plant species without taking into account the regeneration potential of the species $[4,11]$.

\section{Biomed Central}

(c) 2011 Koura et al; licensee BioMed Central Ltd. This is an Open Access article distributed under the terms of the Creative Commons Attribution License (http://creativecommons.org/licenses/by/2.0), which permits unrestricted use, distribution, and reproduction in any medium, provided the original work is properly cited. 
A number of studies have been conducted on P. biglobosa in the West African sub-region and particularly in Benin. In West Africa, previous research has focused on the distribution of the species' populations, phenology, reproductive system, vegetative multiplication, biology and ecology of reproduction [2]. In the parklands in Benin, P. biglobosa was morphologically and structurally characterized and fruit production was assessed on the basis of floristic inventory and measurement of reproductive organ sizes [9]. From microbiological and physico-chemical points of view, it was noted that $P$. biglobosa' seeds could be fermented for the production of "afitin", "iru" and "sonru" (local names for condiments from the seeds of P. biglobosa) [12,13]. Volatile and aromatic compounds were also identified in these condiments in order to obtain, products of aromatic characteristics demanded by consumers. The place and role of this tree in the daily life of rural communities has been investigated [2,10,14,15].

Several research studies have been carried out on "use values" and "use patterns" of different species (such as Adansonia digitata, Khaya senegalensis, Milicia excelsa, Caesalpinia bonduc, Sclerocarya birrea) elsewhere [16-21] and in Benin [22-29]. However, little scientific information is available on quantitative descriptors of $P$. biglobosa's utilization, especially the "use values" and "use patterns" of the species by local communities of Northern Benin. The present study was set up to address the following questions: (1) What ethnobotanical knowledge do local communities have on the use of P. biglobosa? (2) What factors (ethnic group, sex and age) can be used to predict local communities' knowledge on the use of $P$. biglobosa? These questions are based on quantitative measures currently used in ethnobotanical studies $[18,30]$.

\section{Methods}

\section{Study area}

The study was carried out in Northern Benin, where the species widely grows. Northern Benin has four Departments (administrative subdivisions): Alibori, Donga, Borgou and Atacora (Figure 1). Each Department is divided into municipalities and each municipality has several villages. These Departments occupy a total area of 83723 $\mathrm{km}^{2}$, or $74 \%$ of the total area of Benin $\left(112622 \mathrm{~km}^{2}\right)$. They belong to two climatic zones of Benin: the Sudanian climatic zone (between $9^{\circ} 45^{\prime}-12^{\circ} 25^{\prime} \mathrm{N}$ ) and the Sudano-Guinean climatic zone (between $7^{\circ} 30^{\prime}-9^{\circ} 45^{\prime}$ $\mathrm{N})$. The rainfall in these two zones is unimodal. The Sudanian climatic zone is a woodland and savanna region with ferruginous soils. The mean annual temperature is $35^{\circ} \mathrm{C}$. The mean annual rainfall varies between $900 \mathrm{~mm}$ - $1100 \mathrm{~mm}$. The Sudano-Guinean climatic zone is a transitional zone between the sub- humid Guinean zone and the Sudanian zone. This zone is characterized by a vegetation mosaic of forest islands, gallery forests and savannas. The population of the study area was estimated at 2,144,743 inhabitants and the farm population was $1,637,434$ inhabitants [31]. The dominant ethnic groups in the study area are: Bariba, Fulani, Dendi, Mokolé, Berba, Waama, Lokpa, Yom and Nago. Other groups such as Otamari, Boko, Anii and Foodo are also present. Livelihood activities carried out by the people of these ethnic groups include agriculture, ranching, fishing, hunting, processing of agricultural products, trade and craft. The processing of agricultural products is mainly practiced by women individually or in groups with handicraft equipment. The main processed materials are Vitellaria paradoxa nuts (transformed into butter), seeds of Parkia biglobosa (transformed into a food condiment with a ready market), the seeds of Sorghum bicolor (transformed into an alcoholic beverage and also used in some traditional ceremonies), pods of Arachis hypogea (transformed into oil).

\section{Data collection}

All municipalities of the study area and all villages of the selected municipalities were subjected into a hierarchical cluster analysis based on demographic data collected at the National Institute of Statistics and Economic Analyses of the Republic of Benin.

In each selected village, the sample size (n) used for the study was computed based on the following formula [32]:

$$
n=\frac{\bigcup_{1}^{2}-\alpha_{/ 2} p(1-p)}{d^{2}} \text { where, }
$$

$\mathrm{n}$ is the total number of surveyed people in the study; $\bigcup_{1-\alpha / 2}^{2}$ is the value of the normal random variable for a probability value of $\alpha=0.05, \bigcup_{1-\alpha_{/ 2}}=1.96$;

$\mathrm{p}$ is the estimated proportion of people in the village which was involved in the production, processing and/ or marketing of $P$. biglobosa. During an exploration phase, it was noticed that most of the rural households used the $P$. biglobosa species as producers or processors or traders. In this study, p was taken as the ratio of agricultural population and total population of each selected village;

$\mathrm{d}$ is the expected error margin of any parameter to be computed from the survey, which is fixed at 0.1.

After estimating the sample size, local people were randomly selected. The target groups consisted of traders, traditional healers and farmers. Table 1 summarizes the sample size of people surveyed by Department, ethnic group, sex and age group. Semi- 


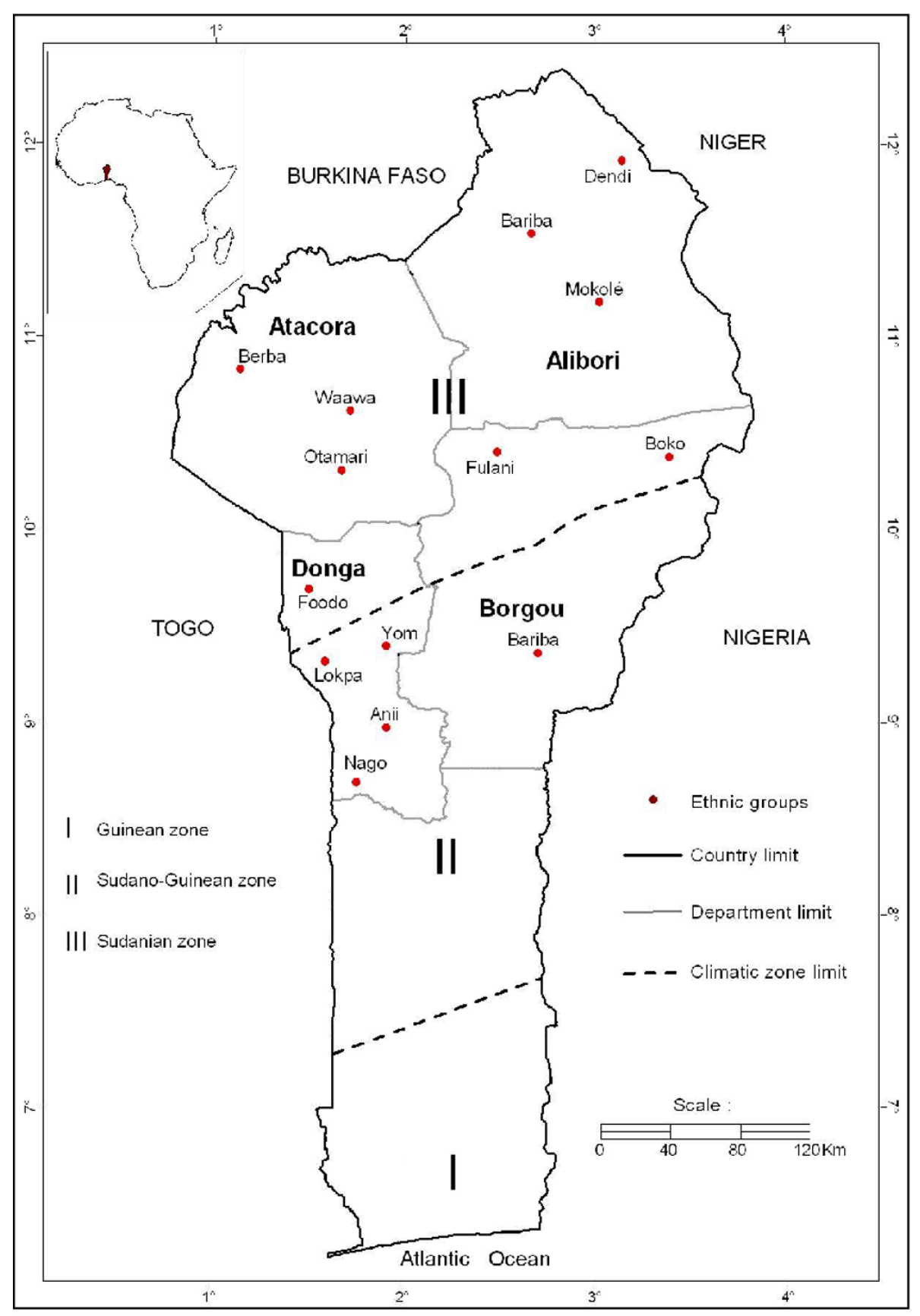

Figure 1 Study area and ethnic groups studied in Northern Benin. This map has been devised and carried out by the authors.

structured interviews surveys were conducted among various people from 13 ethnic groups in the study area, namely Berba, Waama, Otamari, Anii, Nago, Lokpa, Yom, Foodo, Dendi, Mokolé, Bariba, Boko and Fulani. The questionnaire was tailored for each category of target group. The questionnaire evaluated information concerning demographic characteristics (name, sex, age, ethnic group and main activity) and use forms of $P$. biglobosa.

\section{Data analysis}

For ethnobotanical data analysis, the following indices were used: (1) the interviewee diversity value (ID); (2) the interviewee equitability value (IE); (3) the consensus value for plant parts (CPP); (4) the use diversity value (UD); (5) the use equitability value (UE) and (6) the consensus value for the form of use (CMU). Table 2 provides a detailed explanation of each index. These parameters indicate how the species is used and how 
Table 1 Sample size per Department, ethnic group, sex and age.

\begin{tabular}{|c|c|c|c|c|c|c|c|}
\hline \multirow[t]{2}{*}{ Department } & \multirow[t]{2}{*}{ Sample size } & \multirow[t]{2}{*}{ Ethnic group } & \multicolumn{2}{|l|}{ Sex } & \multicolumn{2}{|l|}{ Age } & \multirow[t]{2}{*}{ Total per ethnic group } \\
\hline & & & Men & Women & $\geq 40$ years & $<40$ years & \\
\hline \multirow[t]{3}{*}{ Atacora } & 401 & Berba & 36 & 34 & 59 & 11 & 70 \\
\hline & & Waama & 152 & 89 & 182 & 59 & 241 \\
\hline & & Otamari & 62 & 28 & 59 & 31 & 90 \\
\hline \multirow[t]{5}{*}{ Donga } & 585 & Anii & 64 & 2 & 55 & 11 & 66 \\
\hline & & Nago & 57 & 6 & 53 & 10 & 63 \\
\hline & & Lokpa & 257 & 29 & 173 & 113 & 286 \\
\hline & & Yom & 99 & 30 & 97 & 32 & 129 \\
\hline & & Foodo & 40 & 1 & 29 & 12 & 41 \\
\hline \multirow[t]{3}{*}{ Alibori } & 311 & Dendi & 59 & 29 & 76 & 12 & 88 \\
\hline & & Mokolé & 43 & 15 & 46 & 12 & 58 \\
\hline & & Bariba & 122 & 43 & 107 & 58 & 165 \\
\hline \multirow[t]{3}{*}{ Borgou } & 290 & Boko & 42 & 11 & 43 & 10 & 53 \\
\hline & & Fulani & 93 & 21 & 98 & 16 & 114 \\
\hline & & Bariba & 89 & 34 & 101 & 22 & 123 \\
\hline Total & 1587 & - & 1215 & 372 & 1178 & 409 & 1587 \\
\hline
\end{tabular}

the knowledge of these uses is distributed among the interviewees (table 2). To compute the use diversity value (UD), specific uses of $P$. biglobosa were classified into different categories of uses.

The normality and homogeneity of the ID and IE indices calculated were audited and the non parametric Kruskal-Wallis test, using Minitab, was carried out to assess significant differences related to sex, age and ethnic group. The consensus value for plant parts (CPP) and the consensus value for the form of usage (CMU) calculated per ethnic group were subjected to Principal Component Analysis (PCA) using SAS 9.1 software to better describe the relationship between these use values and the ethnic groups.
Moreover, the retention degree of the medicinal recipes in each ethnic group was determined from the diversity index of Simpson (1/D); which is calculated from the Simpson index (D) as follows:

$$
D=\sum_{i=1}^{S} \frac{n i(n i-1)}{N(N-1)}
$$

with $\mathrm{S}$ being the total number of interviewees per ethnic group; N, arithmetic sum of ni recipes and ni, the number of recipes per interviewee. The diversity index of Simpson (1/D) ranges from 1 to S. If $1 / D$ tends to S, the recipes are shared by everyone in the group. When

Table 2 Indices of knowledge and uses calculated for P. biglobosa.

\begin{tabular}{|c|c|c|c|}
\hline Index & Calculation & Description & Reference \\
\hline $\begin{array}{l}\text { Interviewee diversity } \\
\text { value (ID) } \\
I D=U x / U t\end{array}$ & $\begin{array}{l}\text { ID, number of uses-citations by a given interviewee }(\mathrm{Ux}) \\
\text { divided by the total number of uses }(\mathrm{Ut})\end{array}$ & $\begin{array}{l}\text { Measures how many interviewees used Parkia } \\
\text { biglobosa and how its uses are distributed among the } \\
\text { interviewees }\end{array}$ & [17] \\
\hline $\begin{array}{l}\text { Interviewee } \\
\text { equitability value (IE) } \\
\mathrm{IE}=\mathrm{ID} / \mathrm{IDmax}\end{array}$ & $\begin{array}{l}\mathrm{IE} \text {, interviewee diversity value (ID) divided by this index's } \\
\text { maximum value (IDmax) }\end{array}$ & $\begin{array}{l}\text { Measures the degree of homogeneity of the } \\
\text { interviewee's knowledge }\end{array}$ & [17] \\
\hline $\begin{array}{l}\text { Consensus value for } \\
\text { plant parts (CPP) } \\
\text { CPP }=\text { Px/Pt }\end{array}$ & $\begin{array}{l}\text { CPP, number of times a given plant part was cited }(\mathrm{Px}) \\
\text { divided by the total number of citations of all parts }(\mathrm{Pt})\end{array}$ & $\begin{array}{l}\text { Measures the degree of agreement among } \\
\text { interviewees concerning the plant part used }\end{array}$ & [18] \\
\hline $\begin{array}{l}\text { Use diversity value } \\
\text { (UD) } \\
\text { UD }=U c x / U c t\end{array}$ & $\begin{array}{l}\text { UD, number of indications recorded by category (Ucx) } \\
\text { divided by the total number of indications for all } \\
\text { categories (Uct) }\end{array}$ & $\begin{array}{l}\text { Measures the importance of the use categories and } \\
\text { how they contribute to the total value of uses }\end{array}$ & [17] \\
\hline $\begin{array}{l}\text { Use equitability } \\
\text { value (UE) } \\
\text { UE }=\text { UD/UDmax }\end{array}$ & $\begin{array}{l}\text { UE, use-diversity value (UD) divided by the index's } \\
\text { maximum value (UDmax) }\end{array}$ & $\begin{array}{l}\text { Measures the degree of homogeneity of knowledge } \\
\text { about use categories }\end{array}$ & [17] \\
\hline $\begin{array}{l}\text { Consensus value for } \\
\text { the form of use } \\
(\mathrm{CMU}) \\
\mathrm{CMU}=\mathrm{Mx} / \mathrm{Mt}\end{array}$ & $\begin{array}{l}\mathrm{CMU} \text {, number of citations for a given form of use }(\mathrm{Mx}) \\
\text { divided by the total number of citations for all forms (Mt) }\end{array}$ & $\begin{array}{l}\text { Measures the degree of agreement among } \\
\text { interviewees concerning the form of use of Parkia } \\
\text { biglobosa }\end{array}$ & [18] \\
\hline
\end{tabular}


$1 / \mathrm{D}$ approached 1 , the recipes were only retained by a small group of people.

\section{Results \\ Diversity and distribution of knowledge among interviewees}

All farmers and traditional healers surveyed in the study area used $P$. biglobosa. The values for total diversity value (ID) and total equitability value (IE) were generally high (> 0.50 ) and indicated that knowledge related to P. biglobosa was distributed homogeneously within the target groups (table 3 ). The additional file 1;2; 3 and 4 give more detail on the quantitative measurements of knowledge about $P$. biglobosa in the different Department of the study area. Ethnic group, sex, age and locality (Department) were important factors relating to knowledge distribution. In the Borgou Department, the values of these indices were significantly different among ethnic groups $(\mathrm{p}=0.001)$. These differences, within Borgou, were due to the fact that some interviewees had little knowledge on the species. This was the case in young Fulani women. In the Atacora Department, the ID and IE values for traditional healers differed significantly. These differences were due to the fact that knowledge of P. biglobosa were more diversified and more distributed within Waama aged men (ID $=0.10$ and $\mathrm{IE}=0.40)$ than within young Otamari men (ID = 0.008 and IE $=0.03)$. In the Donga Department, the ID and IE values calculated for the farmers were significantly different among ethnic groups. These differences were due to the fact that knowledge of P. biglobosa was more diversified and more distributed within Lokpa men (ID $=0.36$ and IE $=0.52$ ) than within young Nago and Foodo men (ID $=0.04$ and $\mathrm{IE}=0.06$ for each ethnic group). In the study area, processing activities and sale of organs and products from $P$. biglobosa were mainly conducted by women.

\section{Use diversity value}

Uses of P. biglobosa were grouped into different categories: medicinal (47\% of the interviewees), food (25\%), commercial (22\%), handicrafts and domestic (3\%), medico-magic (1\%), veterinary (1\%) and cultural (1\%). In each Department, whatever the ethnic group, most interviewees mentioned medicinal uses (table 4).

The medicinal uses of the species were the most diversified. Particularly, the digestive system diseases (diarrhoea, dysentery, abdominal pain), diseases of the cardiovascular system, injuries and burns, infectious diseases (shingles, malaria, abscesses, yellow fever, scabies, measles, chicken-pox, edema, jaundice), pediatric pathologies, symptoms and syndromes (malaise, tiredness, headaches, hip pain, ache, rheumatism, excessive weight loss, elephantiasis, onset of paralysis) were reported by most interviewees.

The food uses (transformation of the seeds in condiment, consumption of pulp) and commercial uses (sale of seeds, condiment from seeds, pulp, sponge from roots, wood fire) were observed for all ethnic groups surveyed. These findings demonstrate the importance of $P$. biglobosa in eating habits as well as in the improvement of agricultural households' income. The seeds and pulp (the most marketed plant parts) are an important source of income for farmers. They sell the seeds to the women who invest in the processing of seeds in food condiment. This condiment is appreciated in the study area.

\section{Parkia biglobosa plant parts used}

The P. biglobosa parts used were: fruits [shell (2\%), pulp $(22 \%)$ and seeds $(36 \%)$ ], bark (17\%), leaves $(9 \%)$, roots (3\%), flowers (1\%) and branches (10\%). The fruits (seeds and pulp), bark, leaves and branches were the organs most used. The results of the Principal Component Analysis (PCA) performed on the overall consensus values on $P$. biglobosa parts regarding ethnic groups (table 5) showed that the first two axes accounted for $75.22 \%$ of the total variation. Therefore, only these axes were retained to describe the relationship between $P$. biglobosa parts and ethnic groups. Table 6 shows the correlation coefficient between the different parts and

Table 3 Summary of quantitative measurements of knowledge about $P$. biglobosa

\begin{tabular}{|c|c|c|c|c|c|c|c|c|}
\hline \multirow[t]{2}{*}{ Department } & \multicolumn{4}{|l|}{ Farmers } & \multicolumn{4}{|l|}{ Traditional Healers } \\
\hline & $\begin{array}{l}\text { Total number of } \\
\text { interviewees }\end{array}$ & $\begin{array}{l}\text { Number of uses } \\
\text { cited }\end{array}$ & $\begin{array}{l}\text { Total ID } \\
\text { (p) }\end{array}$ & $\begin{array}{l}\text { Total IE } \\
\text { (p) }\end{array}$ & $\begin{array}{l}\text { Total number of } \\
\text { interviewees }\end{array}$ & $\begin{array}{l}\text { Number of uses } \\
\text { cited }\end{array}$ & $\begin{array}{l}\text { Total ID } \\
\text { (p) }\end{array}$ & $\begin{array}{l}\text { Total IE } \\
\text { (p) }\end{array}$ \\
\hline Alibori & 219 & 25 & $\begin{array}{l}0.99 \\
(0.308)\end{array}$ & $\begin{array}{l}0.99 \\
(0.308)\end{array}$ & 27 & 19 & $\begin{array}{l}0.98 \\
(0.139)\end{array}$ & $\begin{array}{l}0.98 \\
(0.139)\end{array}$ \\
\hline Borgou & 218 & 47 & $\begin{array}{l}0.52 \\
(0.001)\end{array}$ & $\begin{array}{l}0.81 \\
(0.001)\end{array}$ & 20 & 40 & $\begin{array}{l}0.71 \\
(<0.001)\end{array}$ & $\begin{array}{l}0.83 \\
(<0.001)\end{array}$ \\
\hline Atacora & 230 & 19 & $\begin{array}{l}0.58 \\
(0.151)\end{array}$ & $\begin{array}{l}0.79 \\
(0.151)\end{array}$ & 42 & 42 & $\begin{array}{l}0.23 \\
(0.020)\end{array}$ & $\begin{array}{l}0.88 \\
(0.020)\end{array}$ \\
\hline Donga & 488 & 76 & $\begin{array}{l}0.61 \\
(0.012)\end{array}$ & $\begin{array}{l}0.87 \\
(0.012)\end{array}$ & 41 & 47 & $\begin{array}{l}0.43 \\
(0.362)\end{array}$ & $\begin{array}{l}0.51 \\
(0.362)\end{array}$ \\
\hline
\end{tabular}

* ID = Interviewee Diversity value; IE = Interviewee Equitability value; $\mathrm{p}=$ level of signification 
Table 4 Use diversity value (UD) and equitability value (UE) according to various uses of $P$. biglobosa

\begin{tabular}{|c|c|c|c|c|c|c|c|c|c|c|c|c|c|c|c|c|c|c|c|c|c|c|c|c|c|c|c|c|}
\hline \multirow[t]{3}{*}{ Category of use } & \multicolumn{6}{|c|}{ Alibori } & \multicolumn{6}{|c|}{ Borgou } & \multicolumn{6}{|c|}{ Atacora } & \multicolumn{10}{|c|}{ Donga } \\
\hline & \multicolumn{2}{|c|}{ Dendi } & \multicolumn{2}{|c|}{ Mokolé } & \multicolumn{2}{|c|}{ Bariba } & \multicolumn{2}{|c|}{ Bariba } & \multicolumn{2}{|c|}{ Fulani } & \multicolumn{2}{|c|}{ Boko } & \multicolumn{2}{|c|}{ Berba } & \multicolumn{2}{|c|}{ Waama } & \multicolumn{2}{|c|}{ Otamari } & \multicolumn{2}{|l|}{ Anii } & \multicolumn{2}{|c|}{ Nago } & \multicolumn{2}{|c|}{ Lokpa } & \multicolumn{2}{|l|}{ Yom } & \multicolumn{2}{|c|}{ Foodo } \\
\hline & UD & UE & UD & UE & UD & UE & UD & UE & UD & UE & UD & UE & UD & UE & UD & UE & UD & UE & UD & UE & UD & UE & UD & UE & UD & UE & UD & UE \\
\hline Medicinal & 0.72 & 1 & 0.75 & 1 & 0.72 & 1 & 0.62 & 1 & 0.69 & 1 & 0.63 & 1 & 0.76 & 1 & 0.54 & 1 & 0.46 & 1 & 0.67 & 1 & 0.6 & 1 & 0.64 & 1 & 0.70 & 1 & 0.59 & 1 \\
\hline Medico-magic & - & - & - & - & - & - & 0.12 & 0.19 & 0.14 & 0.2 & 0.05 & 0.08 & - & - & 0.14 & 0.26 & - & - & 0.12 & 0.17 & 0.11 & 0.19 & 0.10 & 0.16 & 0.14 & 0.19 & 0.09 & 0.15 \\
\hline Veterinary & - & - & - & - & - & - & - & - & - & - & - & - & - & - & - & - & 0.09 & 0.2 & - & - & 0.02 & 0.04 & 0.03 & 0.05 & - & - & - & - \\
\hline Cultural & - & - & - & - & - & - & 0.02 & 0.03 & - & - & 0.03 & 0.04 & 0.04 & 0.05 & 0.06 & 0.11 & - & - & - & - & - & - & 0.03 & 0.05 & - & - & - & - \\
\hline Handicrafts and domestic & 0.04 & 0.06 & 0.04 & 0.06 & 0.04 & 0.06 & 0.05 & 0.08 & 0.05 & 0.08 & 0.05 & 0.08 & 0.04 & 0.05 & 0.09 & 0.16 & 0.09 & 0.2 & 0.07 & 0.10 & 0.11 & 0.19 & 0.09 & 0.13 & 0.03 & 0.04 & 0.14 & 0.23 \\
\hline Food & 0.12 & 0.17 & 0.13 & 0.17 & 0.12 & 0.17 & 0.09 & 0.14 & 0.02 & 0.03 & 0.11 & 0.17 & 0.08 & 0.11 & 0.09 & 0.16 & 0.18 & 0.4 & 0.07 & 0.10 & 0.04 & 0.07 & 0.05 & 0.08 & 0.05 & 0.08 & 0.09 & 0.15 \\
\hline Commercial & 0.12 & 0.17 & 0.08 & 0.11 & 0.12 & 0.17 & 0.10 & 0.17 & 0.10 & 0.15 & 0.13 & 0.21 & 0.08 & 0.11 & 0.09 & 0.4 & 0.18 & 0.4 & 0.07 & 0.10 & 0.11 & 0.19 & 0.05 & 0.08 & 0.08 & 0.12 & 0.09 & 0.15 \\
\hline
\end{tabular}


Table 5 Consensus values for Parkia biglobosa parts (CPP)

\begin{tabular}{|c|c|c|c|c|c|c|c|c|c|c|c|c|c|c|}
\hline \multirow[t]{2}{*}{ Parts } & \multicolumn{3}{|l|}{ Alibori } & \multicolumn{3}{|l|}{ Borgou } & \multicolumn{3}{|c|}{ Atacora } & \multicolumn{5}{|c|}{ Donga } \\
\hline & Dendi & Mokolé & Bariba & Bariba & Fulani & Boko & Berba & Waama & Otamari & Anii & Nago & Lokpa & Yom & Foodo \\
\hline Bark & 0.25 & 0.235 & 0.271 & 0.114 & 0.068 & 0.063 & 0.198 & 0.146 & 0.118 & 0.173 & 0.183 & 0.201 & 0.189 & 0.248 \\
\hline Leaves & 0.156 & 0.139 & 0.133 & 0.089 & 0.041 & 0.043 & 0.102 & 0.063 & 0.055 & 0.07 & 0.107 & 0.088 & 0.059 & 0.203 \\
\hline Roots & 0.04 & 0.036 & 0.069 & 0.018 & 0.007 & 0.013 & - & 0.023 & 0.059 & 0.096 & 0.127 & 0.023 & 0.016 & 0.03 \\
\hline Seeds & 0.375 & 0.398 & 0.352 & 0.253 & 0.341 & 0.275 & 0.353 & 0.402 & 0.349 & 0.368 & 0.317 & 0.414 & 0.519 & 0.391 \\
\hline Pulp & 0.156 & 0.054 & 0.09 & 0.253 & 0.341 & 0.275 & 0.198 & 0.193 & 0.261 & 0.272 & 0.183 & 0.255 & 0.205 & 0.12 \\
\hline Shells of fruits & 0.022 & 0.018 & 0.024 & 0.06 & 0.032 & 0.02 & - & - & 0.004 & 0.018 & 0.048 & 0.01 & 0.011 & 0.008 \\
\hline Flowers & - & - & - & - & 0.007 & - & - & - & - & - & - & - & - & - \\
\hline Branches & - & 0.12 & 0.06 & 0.213 & 0.161 & 0.311 & 0.150 & 0.173 & 0.155 & 0.004 & 0.036 & 0.009 & - & - \\
\hline
\end{tabular}

the two axes. The first axis shows a positive link between bark, leaves, roots, seeds and pulp. Axis 2 shows the positive link between flowers and branches. Moreover, Figure 2 shows the projection of different ethnic groups into the system axes 1 and 2. From these observations, it can be deduced that Lokpa, Waama and Bariba ethnic groups assigned a high consensus value for bark, leaves, roots, seeds and pulp. In contrast, Nago, Anii, Dendi, Otamari, Mokolé, Foodo, Yom, Berba, Boko and Fulani assigned low value to bark and leaves. Ethnobotanical consensus values for branches were high for Fulani, Waama and Boko but low for other ethnic groups.

\section{Forms of use of Parkia biglobosa}

The different forms of use of P. biglobosa in the study area were: decoction, maceration, filtration, powder, boiled pulp, sponge, vegetable brush (toothpick), condiment derivative of seeds/potash, direct consumption, pounding, small cushion (leaves of $P$. biglobosa rolled as a cushion), chewing, consumption after cooking on embers, soap and frankincense (table 7). The results of the Principal Component Analysis (PCA) performed on the overall consensus values per form of use by ethnic groups, showed that the first two axes explained $60.31 \%$ of the total variation. Therefore, only these axes were used to describe the relationship between use forms and ethnic groups. Figure 3 shows the projection of different

Table 6 Correlation between P. biglobosa parts and PCA axes

\begin{tabular}{lll}
\hline Parts & Axis 1 & Axis 2 \\
\hline Bark & 0.954 & -0.195 \\
Leaves & 0.952 & -0.158 \\
Roots & 0.733 & -0.306 \\
Seeds & 0.915 & 0.006 \\
Pulp & 0.876 & 0.219 \\
Shells & 0.714 & 0.230 \\
Flowers & -0.041 & 0.897 \\
Branches & 0.426 & 0.551 \\
\hline
\end{tabular}

ethnic groups into the system axes 1 and 2 . The correlation coefficient between the different use forms and the first axis showed a positive link between decoction, maceration, filtration, condiment, powder, sponge, pounding and direct consumption. Axis 2 shows a positive link between vegetable brush (toothpick), pounding, powder, consumption after cooking on embers and soap. We therefore deduce that ethnobotanical consensus values for decoction, maceration, filtration, condiment, powder, sponge, pounding and direct consumption use forms were high for Bariba, Dendi, Fulani, Waama and Lokpa but low for other ethnic groups. Vegetable brush (toothpick), pounding, powder, consumption after cooking on embers, soap consensus values were high for Lokpa, Anii, Foodo and Yom but low for other ethnic groups.

The Simpson's diversity indices for different ethnic groups were significantly lower than S, i.e. the number of interviewees per ethnic group (table 8), meaning that each respondent knew practically at least one use of $P$. biglobosa. Each respondent had their way of using the species. Taking into account the Simpson's diversity indices and coefficients of variation, it can be concluded that the recipes are diversified and vary according to ethnic group.

\section{Discussion}

This work has demonstrated that Parkia biglobosa is a multipurpose species in Benin. The species is used in multiple ways. The ethnobotanical indices (quantitative measures) allowed for the reaching of consensus among interviewees on the uses of the species. The approach assumes that there is no relationship between what the interviewee says and what he or she actually does. These quantitative measures reflect a consensus among interviewees, based on the understanding that culture represents shared knowledge [16]. The importance and usefulness of collecting local communities' knowledge lie in the fact that such information could help determining the true value of the species, leading to more rational decisions about its sustainable utilization. 


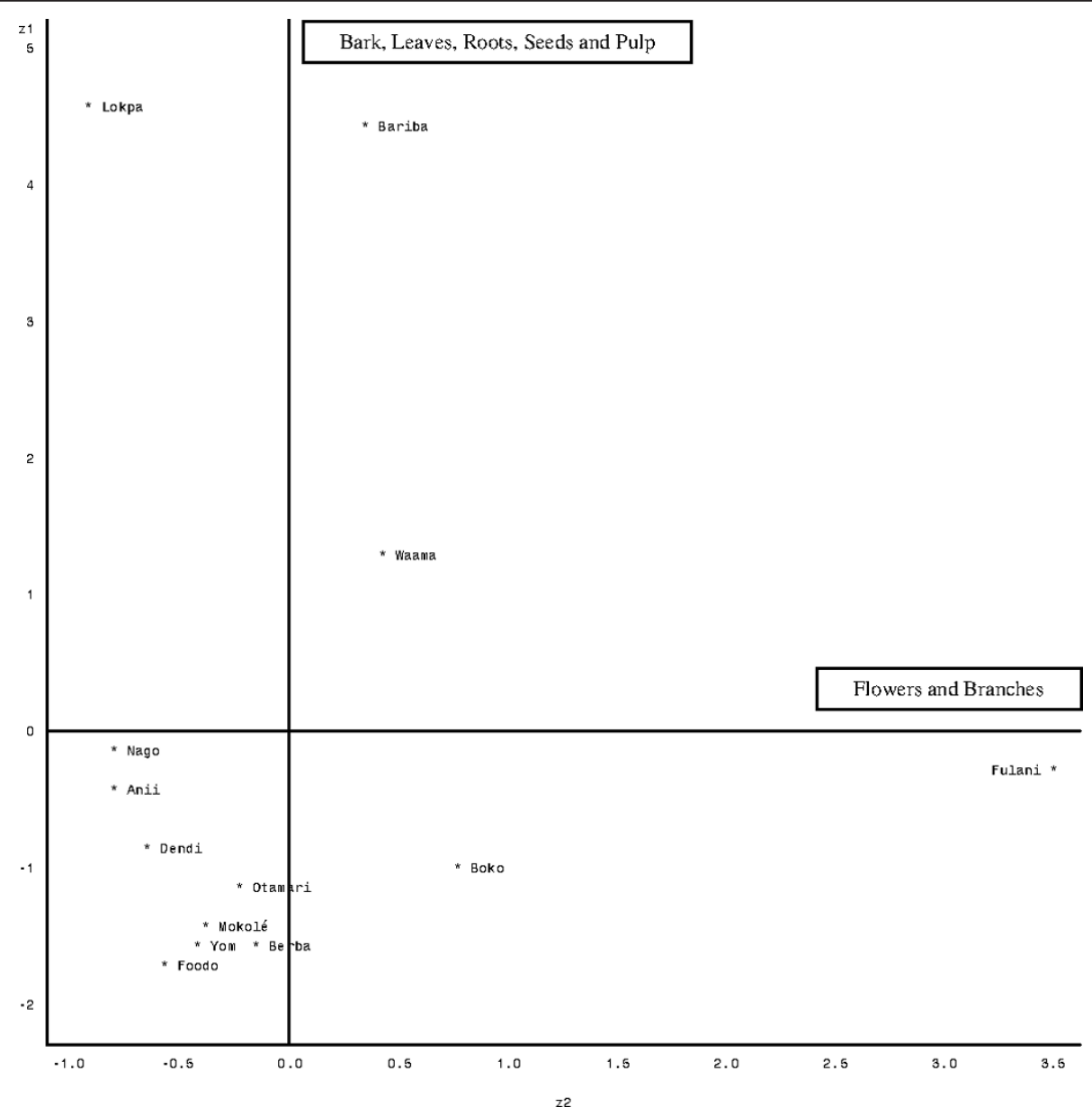

Figure 2 Projection of targeted ethnic groups in the system axis defined by the different organs.

Table 7 Consensus values for Parkia biglobosa forms of usage (CMU)

\begin{tabular}{|c|c|c|c|c|c|c|c|c|c|c|c|c|c|c|}
\hline \multirow[t]{2}{*}{ Forms of use } & \multicolumn{3}{|l|}{ Alibori } & \multicolumn{3}{|l|}{ Borgou } & \multicolumn{3}{|c|}{ Atacora } & \multicolumn{5}{|c|}{ Donga } \\
\hline & Dendi & Mokolé & Bariba & Bariba & Fulani & Boko & Berba & Waama & Otamari & Anii & Nago & Lokpa & Yom & Foodo \\
\hline Decoction & 0.274 & 0.289 & 0.293 & 0.195 & 0.141 & 0.257 & 0.245 & 0.367 & 0.151 & 0.103 & 0.103 & 0.099 & 0.16 & 0.123 \\
\hline Maceration & 0.137 & 0.104 & 0.133 & 0.047 & 0.025 & 0.029 & 0.06 & 0.036 & 0.086 & 0.06 & 0.103 & 0.072 & 0.08 & 0.046 \\
\hline Filtration & 0.16 & 0.121 & 0.102 & 0.053 & 0.075 & 0.214 & 0.007 & 0.036 & - & - & 0.019 & 0.041 & - & - \\
\hline Powder & 0.032 & 0.064 & 0.038 & 0.005 & 0.05 & - & 0.03 & 0.007 & 0.046 & 0.128 & 0.058 & 0.051 & 0.024 & 0.077 \\
\hline Boiled pulp & 0.137 & 0.116 & 0.091 & 0.045 & 0.033 & 0.029 & 0.323 & 0.281 & 0.355 & 0.12 & 0.116 & 0.206 & 0.096 & 0.169 \\
\hline Sponge & 0.005 & 0.006 & 0.087 & - & - & - & - & - & - & 0.085 & 0.129 & 0.01 & 0.008 & 0.015 \\
\hline Vegetable brush (toothpick) & 0.005 & 0.006 & 0.022 & - & - & - & 0.012 & 0.007 & 0.007 & 0.154 & 0.2 & 0.362 & 0.424 & 0.308 \\
\hline $\begin{array}{l}\text { Seeds/potash derived } \\
\text { condiment }\end{array}$ & 0.251 & 0.295 & 0.233 & 0.321 & 0.394 & 0.243 & 0.307 & 0.245 & 0.349 & 0.205 & 0.148 & 0.041 & 0.08 & 0.031 \\
\hline Direct consumption & - & - & - & 0.216 & 0.266 & 0.186 & - & - & - & - & - & - & - & - \\
\hline Pounding & - & - & - & 0.118 & 0.017 & 0.043 & - & - & - & 0.12 & 0.097 & 0.111 & 0.128 & 0.169 \\
\hline Small cushion & - & - & - & - & - & - & 0.002 & 0.014 & - & - & - & - & - & - \\
\hline Chewing & - & - & - & - & - & - & 0.014 & 0.007 & 0.007 & - & - & - & - & - \\
\hline $\begin{array}{l}\text { Consumption after cooking on } \\
\text { embers }\end{array}$ & - & - & - & - & - & - & - & - & - & 0.017 & 0.006 & 0.004 & - & 0.015 \\
\hline Soap & - & - & - & - & - & - & - & - & - & 0.009 & 0.013 & 0.002 & - & 0.046 \\
\hline Frankincense & - & - & - & - & - & - & - & - & - & - & 0.006 & - & - & - \\
\hline
\end{tabular}




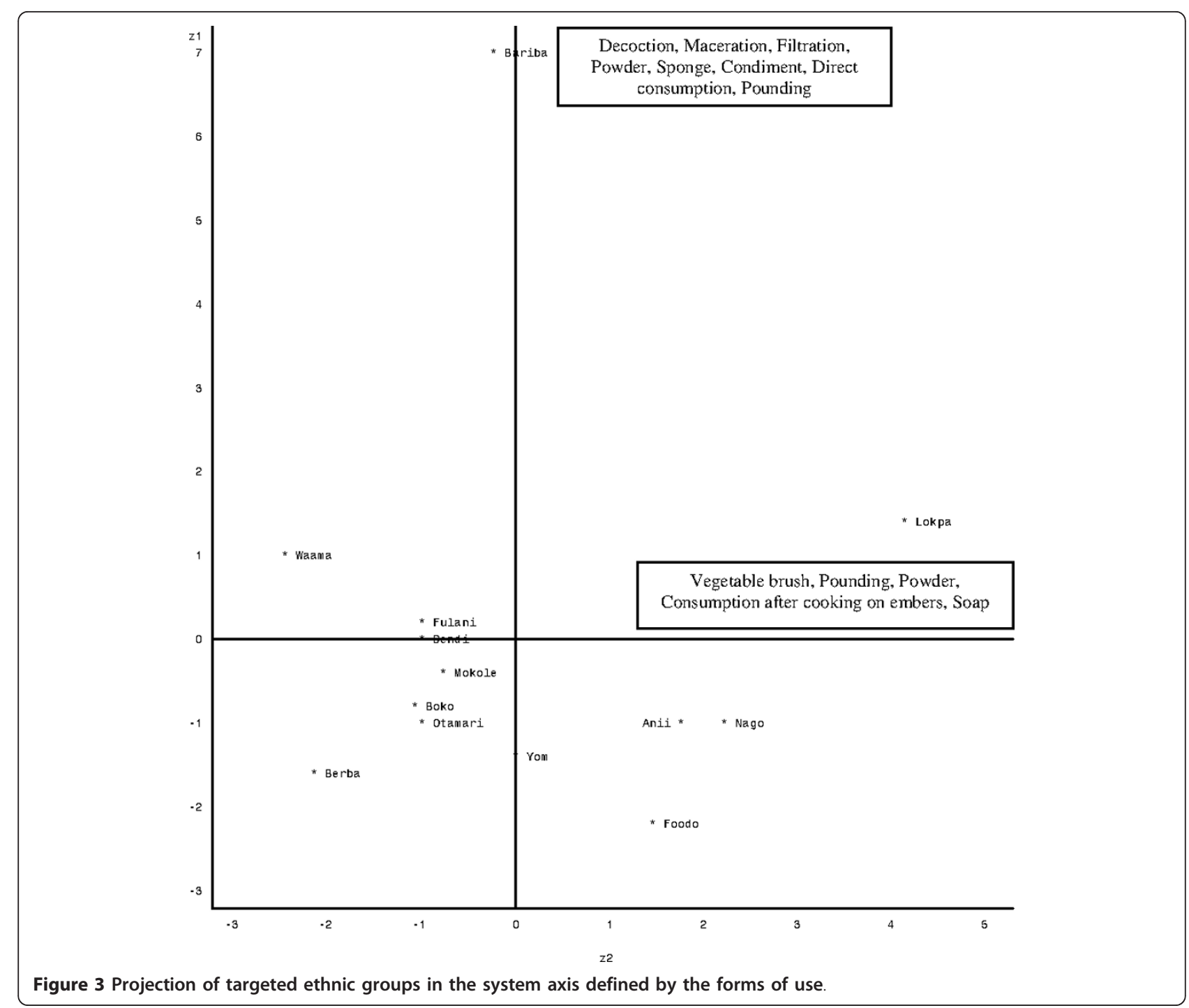

Knowledge of the local usage of vegetable resources is essential for the elaboration of conservation strategies [33]. This is the first time that the use values according to various ethnic groups in the study area have been evaluated in detail for P. biglobosa.

Overall, we found significant ethnic variation in knowledge and use values of P. biglobosa, as has been found for Tamarindus indica [25], Adansonia digitata [22,27,34] and Caesalpinia bonduc [26]. Local knowledge varied not only according to different ethnic groups but also according to the age and sex of individuals interviewed. The results confirm the significant age and gender differences in the use of medicinal plants shown by [19-21] and [35].

This work also identified the various diseases treated by $P$. biglobosa and the recipes used by different ethnic groups, which falls under ethno-herbal medicine. All organs of the tree were widely recognized as being used

Table 8 Simpson's diversity indexes calculated by ethnic group in the study area

\begin{tabular}{|c|c|c|c|c|c|c|c|c|c|c|c|c|c|c|}
\hline \multirow[t]{2}{*}{ Parameters calculated } & \multicolumn{3}{|l|}{ Alibori } & \multicolumn{3}{|l|}{ Borgou } & \multicolumn{3}{|c|}{ Atacora } & \multicolumn{5}{|c|}{ Donga } \\
\hline & Dendi & Mokolé & Bariba & Bariba & Fulani & Boko & Berba & Waama & Otamari & Anii & Nago & Lokpa & Yom & Foodo \\
\hline $\begin{array}{l}\text { Number of interviewees } \\
\text { by ethnic group (S) }\end{array}$ & 69 & 54 & 123 & 50 & 39 & 58 & 47 & 67 & 266 & 64 & 46 & 260 & 109 & 40 \\
\hline $\begin{array}{l}\text { Simpson's diversity index } \\
\text { (1/D) }\end{array}$ & 5.66 & 11.04 & 6.70 & 2.72 & 1.54 & 4.12 & 2.76 & 6.12 & 5.88 & 11.22 & 1.41 & 12.57 & 11.88 & 8.21 \\
\hline
\end{tabular}


for food, medicinal, medico-magical, cultural and others. All parts of the tree (roots to leaves) are valued and used differently by people. Fermented seeds and yellow floury pulp (rich in saccharose) are both highly appreciated as food. In a large part of West Africa [2] particularly in Togo [36], Nigeria [37], Mali [38], Benin [5,15], the food condiment from $P$. biglobosa seeds is the main seasoning sauce. The medicinal' uses of the species is the most diversified. This is general in West Africa where all organs of the species are used as main recipe or in combination with other plants in the treatment of several diseases [39]. Biochemical analysis has shown active compounds in different organs which explain and confirm several indigenous medicinal uses. The organs of $P$. biglobosa are rich in various components such as flavonoid aglycones, fatty acids, tannins, reducing compounds (fructose and glucose), carbohydrates and anthocyanosides [2]. The P. biglobosa products are also rich in protein $[2,40]$ and can therefore be used as protein supplements in diets based mainly on cereals. Therefore, $P$. biglobosa has medicinal potential on which research and development could be derived to develop standardized phytomedicines and reduce the pressure on the species in its natural habitats. It is therefore important to value the food condiment from seeds of $P$. biglobosa since it has a certain nutritional value unlike flavoring imported mainly consisting of glutamate.

The important functions of $P$. biglobosa especially in the food and traditional medicine are the main reasons justifying its conservation in situ. However, $P$. biglobosa is a vulnerable tree species since all plant parts are collected for various purposes. The fruits (seeds and pulp), bark, leaves and branches are the organs most used. Harvesting of bark has more negative impacts on habitat and population of the species than harvesting leaves and fruits [41-45]. However, harvesting of leaves and fruits may also have a negative impact on the regeneration process because the maintenance of regeneration capacity also depends on the maintenance of key regeneration principles such as pollination, development and dispersal of seeds, germination and plant growth. It is therefore necessary to consider strategies for the conservation of valuable species such as P. biglobosa.

\section{Conclusion}

From the present study, we can conclude that Parkia biglobosa is a well-known resource and used in different ways by locals in Benin. Local knowledge on the species is diversified and dependent on sex, age and ethnic group. Knowledge is homogeneously distributed within ethnic groups. All parts of $P$. biglobosa are used for various purposes. Ethnic differences in use values and use patterns of the species were clearly observed in this study. Among all the studied ethnic groups, Lokpa,
Waama and Bariba had the highest level of knowledge on P. biglobosa parts and forms of use while the other ethnic groups had limited level of knowledge. Local knowledge varied not only according to ethnic group but also according to the age and sex of individuals. For instance, knowledge of $P$. biglobosa were more diversified and more distributed within older Waama men and Lokpa men than within young Otamari men, Fulani women and young Nago and Foodo men.

\section{Consent statement}

I attest to the fact that all authors listed on the title page have read the manuscript, attest to the validity and legitimacy of the data and its interpretation, and agree to its submission to Journal of Ethnobiology and Ethnomedicine. Written informed consent was obtained from the participants of this study.

\section{Additional material}

\section{Additional file 1: Quantitative measurements of knowledge about $P$. biglobosa in Alibori Department. \\ Additional file 2: Quantitative measurements of knowledge about $P$. biglobosa in Borgou Department. \\ Additional file 3: Quantitative measurements of knowledge about $P$. biglobosa in Atacora Department. \\ Additional file 4: Quantitative measurements of knowledge about P. biglobosa in Donga Department. The additional file 1; 2; 3 and 4 give more detail on how the data were analyzed by ethnic group, gender group and age group.}

\section{Acknowledgements}

We thank the Scientific Senate of University of Abomey-Calavi which provided financial assistance through "Néré 2ADE" project for which Prof. Dr. Ir. Joseph Hounhouigan was the head. Our acknowledgments also go to Essè Florentin Dissou, Jean-Jaurès Daanon, Médard Djèdji, Mathias Olou and local communities who have helped to this work. We finally thank the anonymous reviewers for their constructive comments on this manuscript.

\section{Author details}

${ }^{1}$ Faculty of Agronomic Sciences, University of Abomey-Calavi, Cotonou (01 PO Box 526), Benin. ${ }^{2}$ Faculty of Sciences and Techniques, University of Abomey-Calavi, Cotonou (01 PO Box 526), Benin.

\section{Authors' contributions}

KK designed and performed the field work, analyzed and drafted the manuscript. AEA gave conceptual advice, read and improved the drafted manuscript. JCG and CA supervised the work and improved the manuscript. All authors have read and approved the final manuscript.

\section{Competing interests}

The authors declare that they have no competing interests.

Received: 15 June 2011 Accepted: 7 December 2011

Published: 7 December 2011

\section{References}

1. Devineau $\mathrm{J}$ : Ecologie des principales espèces ligneuses alimentaires et fourragères dans un système de culture-jachère: Sud-Ouest du BurkinaFaso. Actes du Séminaire International sur la jachère en Afrique tropicale 1316 avril 1999; Dakar; 1996, 441-450. 
2. Ouédraogo A-S: Parkia biglobosa (Leguminosae) en Afrique de l'Ouest: biosystématique et amélioration. Thèse de Doctorat Université Agronomique de Wageningen; 1995.

3. In Réseau "Espèces Ligneuses Médicinales». Compte rendu de la première réunion du Réseau: 15-17 décembre 1999; Station IITA Cotonou, Bénin. Edited by: Eyog-Matig O. Institut International des Ressources Phytogénétiques; 1999:

4. In Réseau "Espèces Ligneuses Alimentaires 》. Compte rendu de la première réunion du Réseau: 11-13 décembre 2000; CNSF Ouagadougou, Burkina Faso. Edited by: Eyog-Matig O, Gaoué OG, Dossou B. Institut International des Ressources Phytogénétiques; 2002:.

5. Sadji B: Contribution à la promotion du néré (Parkia biglobosa) dans les terroirs villageois de la Circonscription Urbaine de Djougou: Cas des villages de Nalohou, Sassero, Soubroukou, Wargou. Mémoire de fin de cycle pour l'obtention du Brevet de Technicien Supérieur Ecole de Spécialisation en Foresterie du Banco, République de Côte d'Ivoire; 2000.

6. Djakpo O: Fermentation contrôlée des graines de néré (Parkia biglobosa) pour la production d'un condiment béninois de type afitin: effets de I'utilisation des souches sélectionnées de Bacillus subtilis sur la qualité du produit. Thèse d'ingénieur Agronome Université d'Abomey-Calavi, Faculté des Sciences Agronomiques; 2005.

7. FAO: Evaluation des ressources en produits forestiers non ligneux 2001.

8. Bonkoungou EG: Monographie du néré, Parkia biglobosa (jaca.) Benth., espèce agroforestière à usages multiples Institut de Recherche en Biologie et Ecologie Tropicale: IRBET/CNRST, Ouagadougou, Burkina Faso; 1987.

9. Gbédji EK: Caractérisation morphologique et structurale des parcs à néré (Parkia biglobosa (Jack.) R. Br. Ex. G. Don.) au Bénin. Thèse d'Ingénieur Agronome Université d'Abomey-Calavi, Faculté des Sciences Agronomiques; 2003.

10. Gutierrez ML, Juhé-Beaulaton D: Histoire du parc à Néré (Parkia biglobosa Jacq. Benth.) sur le plateau d'Abomey (Bénin): de sa conservation pour la production et la commercialisation d'un condiment, l'afitin. Cahiers d'Outre-mer 2002, 220:453-474.

11. Sina S: Reproduction et diversité génétique chez Parkia biglobosa (Jacq.) G. Don. PhD thesis Wageningen University; 2006.

12. Azokpota P, Hounhouigan DJ, Nago MC: Microbiological and chemical changes during the fermentation of African locust bean (Parkia biglobosa) to produce afitin , iru and sonru, three traditional condiments produced in Benin. International Journal of Food Microbiology 2006, 107:304-309.

13. Azokpota P, Hounhouigan DJ, Nago MC, Jakobsen M: Esterase and protease activities of Bacillus spp from afitin , iru and sonru, three African locust bean (Parkia biglobosa) condiments from Benin. African Journal of Biotechnology 2006, 5(Suppl 3):265-272.

14. Fandohan S: Une étude sur l'importance socio-économique de quelques produits de cueillette (Parkia biglobosa Benth, et Irvingia gabonensis Baill) en République Populaire du Bénin. Thèse d'Ingénieur Agronome Université Nationale du Bénin, Faculté des Sciences Agronomiques; 1983.

15. Koura K: Contribution à l'étude ethnobotanique du néré [Parkia biglobosa (Jacq.) R. Br. ex G. Don] dans les départements de l'Atacora et de la Donga: Aspects socioculturels. Mémoire de DESS en Aménagement et Gestion des Ressources Naturelles option Sciences et Techniques Forestières Université d'Abomey-Calavi, Faculté des Sciences Agronomiques; 2003.

16. Reyes-Garcia V, Byron E, Godoy WR, Apaza L, Limache EP, Leonard WR, Wilkie D: Measuring culture as shared knowledge: do data collection formats matter? Cultural knowledge of plants uses among Tsimane' Amerindians, Bolivie. Field Methods 2004, 16(Suppl 2):135-156.

17. Byg A, Baslev H: Diversity and Use of Palms in Zahamena, Eastern Madagascar. Biodiversity and Conservation 2001, 10:951-970.

18. Monteiro JM, Albuquerque UP, Lins Neto EMF, Araùjo EL, Amorim ELC: Use Patterns and Knowledge of Medicinal Species among Two Rural Communities in Brazil's Semi-Arid Northeast-ern Region. Journal of Ethnopharmacology 2006, 105:173-186.

19. Hanazaki N, Tamashiro JY, Leităo-Filho HF, Begosi A: Diversity of plant uses in two Caiçara communities from the Atlantic Forest coast, Brazil. Biodiv Cons 2000, 9:597-615.

20. Augustino S, Gillah PR: Medicinal plants in urban districts of Tanzania: plants, gender roles and sustainable use. Intern Forestry Rev 2005, 7:44-58.

21. Camou-Guerrero A, Reyes-Garcia V, Martínez-Ramos M, Casas A: Knowledge and Use value of Plant Species in a Rarámuri Community: A Gender perspective for Conservation. Hum Ecol 2008, 36:259-272.
22. De Caluwé E, De Smedt S, Assogbadjo AE, Samson R, Sinsin B, Van Damme P: Ethnic Differences in Use Value and Use Patterns of Baobab (Adansonia digitata L.) in Northern Benin. African Journal of Ecology 2009, 47:433-440.

23. Gaoué O, Ticktin T: Fulani Knowledge of the Ecological Impacts of Khaya senegalensis (Meliaceae) Foliage Harvest in Benin and Its Implications for Sustainable Harvest. Econ Bot 2009, 63(Suppl 3):256-270.

24. Ouinsavi C, Sokpon N, Bada O: Utilisation and Strategies of In Situ Conservation of Milicia excelsa Welw, C.C. Berg, in Benin. Forest Ecology and Management 2005, 207:341-350.

25. Fandohan B, Assogbadjo AE, Glèlè Kakaï R, Kyndt T, De Caluwé E, Codjia JTC, Sinsin B: Women's traditional knowledge, use value, and the contribution of tamarind (Tamarindus indica L.) to rural households'cash income in Benin. Economic Botany 2010, 64(3):248-258, Econ. Bot. XX(Suppl X):1-12.

26. Assogbadjo AE, Glèlè Kakaï R, Adjallala FH, Azihou AF, Vodouhê GF, Kyndt T, Codjia JTC: Ethnic differences in use value and use patterns of the threatened multipurpose scrambling shrub (Caesalpinia bonduc L.) in Benin. Journal of Medicinal Plants Research 2010, 5(9):1549-1557.

27. Assogbadjo AE, De Caluwé E, Sinsin B, Codjia J-CT, Van Damme P: Indigenous knowledge of rural people and importance of baobab tree (Adansonia digitata L.) in Benin. In Proceedings of the fourth International Congress of Ethnobotany (ICEB, 2005): 21-26 August 2005. Edited by: Füsun Ertug Z. Yeditepe, University Istanbul, Turkey; 2006:39-47.

28. Vodouhê FG, Coulibaly O, Greene C, Sinsin B: Estimating the local value of non-timber forest products to pendjari biosphere reserve dwellers in Benin. Economic Botany 2009, 63(4):397-412.

29. Gouwakinnou G, Lykke A, Assogbadjo AE, Sinsin B: Local knowledge, pattern and diversity of use of Sclerocarya birrea. Journal of Ethnobiology and Ethnomedicine 2011, 7:8.

30. Silva VA, Albuquerque UP: Técnicas para anàlise de dados etnobotânicos. In Métodos e Técnicas na Pesquisa Etnobotânica. Edited by: Albuquerque UP, Lucena RFP. Recife ed. Livro Ràpido, NUPEEA; 2004:

31. Institut National dela Statistique et de l'Analyse Economique: Cahier des villages et quartiers de ville. Départements de l'Atacora, de la Donga, du Borgou et de I'Alibori Cotonou; 2004.

32. Dagnelie P: Statistiques théoriques et appliquées. Brussels: De Boeck et Larcier. 1998.

33. Achigan-Dako E, N'Danikou S, Assogba-Komlan F, Ambrose-Oji B, Ahanchede A, Pasquini M: Diversity, Geographical, and Consumption Patterns of Traditional Vegetables in Sociolinguistic Communities in Benin: Implications for Domestication and Utilization. Economic Botany 2011, 65:129-145.

34. Assogbadjo AE, Glèlè Kakaï R, Chadaré FJ, Thomson L, Kyndt T, Sinsin B, Van Damme P: Folk Classification, Perception, and Preferences of Baobab Products in West Africa: Consequences for Species Conservation and Improvement. Econ Bot 2008, 62(Suppl 1):74-84.

35. Müller-Schwarze NK: Antes and Hoy Día: Plant knowledge and categorization as adaptations to life in Panama in the twenty-first century. Econ Bot 2006, 60:321-334.

36. Walla K: Typologie, structure et fonctionnement des agrosystèmes traditionnels dans la Préfecture de Doufélgou (Nord-Togo). Mémoire de DESS en Aménagement et Gestion des Ressources Naturelles Université d'Abomey-Calavi; 2001.

37. Sabiiti EN, Cobbina J: Initial agronomic evaluation of Parkia biglobosa in the Humid zone of Nigeria. Agroforestry systems 1992, 17:271-279.

38. Kater LJM, Kanté S, Budelman A: Karité (Vitellaria paradoxa) and néré (Parkia biglobosa) associated with crops in South Mali. Agroforestry systems 1992, 18:89-105.

39. Lejoly J: Liste de 1124 espèces médicinales utilisées dans 11 pays avec indication de la maladie soignée et du nombre de recettes par pays Projet pharmacopée, ACCT: Labo. Bot. Syst. et Phytosoc., Univ. Libre Bruxelles; 1988.

40. Djivoh HYA: Caractérisation physico-chimique des graines de néré et mise au point de méthode de fragilisation. Thèse d'Ingénieur Agronome Université d'Abomey-Calavi, Faculté des Sciences Agronomiques; 2009.

41. Bonati A: Industry and conservation of medicinal plants. In Proceedings of an International Conference: 21-27 March 1988; Chiang Mai, Thailand. Edited by: Akérélé $\mathrm{O}$, Heywood V, Synge $H$. The conservation of medicinal plants; 1991:141-145. 
42. Cunningham AB: Development of the conservation policy on commercially exploited medicinal plant. A case study from southern Africa. In Proceedings of an International Conference: 21-27 March 1988; Chiang Mai, Thailand. Edited by: Akérélé O, Heywood V, Synge H. The conservation of medicinal plants; 1991:337-354.

43. WWF, IUCN, OMS: Principes directeurs pour la conservation des plantes médicinales Switzerland; 1993.

44. Walkers $\mathrm{M}$, Hamilton $\mathrm{A}$ : In La diversité végétale: une source de richesse vitale Edited by: WWF 1994.

45. Cunningham AB: Applied ethnobotany. People, wild plant use and conservation People and plants, Conservation Manuel: Earthscan; 2001.

doi:10.1186/1746-4269-7-42

Cite this article as: Koura et al.: Ethnic differences in use values and use patterns of Parkia biglobosa in Northern Benin. Journal of Ethnobiology and Ethnomedicine 2011 7:42.

\section{Submit your next manuscript to BioMed Central} and take full advantage of:

- Convenient online submission

- Thorough peer review

- No space constraints or color figure charges

- Immediate publication on acceptance

- Inclusion in PubMed, CAS, Scopus and Google Scholar

- Research which is freely available for redistribution

Submit your manuscript at www.biomedcentral.com/submit 